\title{
Bioprocesses for the removal of nitrogen oxides from polluted air
}

Yaomin Jin, María C Veiga, Christian Kennes

Journal of Chemical Technology \& Biotechnology, Volume 80, Issue 5,May 2005

Pages 483-494

DOI: $10.1002 /$ jctb.1260

\begin{abstract}
Nitrogen oxides (NOx) of environmental concern are nitrogen monoxide (NO) and nitrogen dioxide $\left(\mathrm{NO}_{2}\right)$. They are hazardous air pollutants that lead to the formation of acid rain and tropospheric ozone. Both pollutants are usually present simultaneously and are, therefore, called NOx. Another compound is $\mathrm{N}_{2} \mathrm{O}$ which is found in the stratosphere where it plays a role in the greenhouse effect. Concern for environmental and health issues coupled with stringent NOx emission standards generates a need for the development of efficient low-cost NOx abatement technologies. Under such circumstances, it becomes mandatory for each NOx-emitting industry or facility to opt for proper NOx control measures. Several techniques are available to control NOx emissions: selective catalytic reduction (SCR), selective non-catalytic reduction (SNCR), adsorption, scrubbing, and biological methods. Each process offers specific advantages and limitations. Since bioprocesses present many advantages over conventional technologies for flue gas cleaning, a lot of interest has recently been shown for these processes. This article reviews the major characteristics of conventional non-biological technologies and recent advances in the biological removal of NOx from flue gases based on the catalytic activity of either eucaryotes or procaryotes, ie nitrification, denitrification, the use of microalgae, and a combined physicochemical and biological process (BioDeNOx). Relatively uncomplicated design and simple operation and maintenance requirements make biological removal a good option for the control of NOx emissions in stationary sources
\end{abstract}

\section{Keywords:}

Air pollution; nitrogen oxides (NOx); BioDeNOx; nitrification; denitrification; microalgae 


\section{INTRODUCTION}

Anthropogenic emissions of nitrogen oxides (NOx) present various negative effects on ecosystems and human health, such as acidification, eutrophication, increase of groundlevel ozone, contribution to the formation of particulate matter, and loss of biodiversity.1 Global emissions of NOx have followed an almost exponential increase over time, although such increase has started to slow down over the past decade. In Europe the release of nitrogen oxides has even declined recently. However, the growing economies of some regions, especially in southeast Asia, are likely to overwhelm any reductions in NOx emissions that are made in Europe and North America.2 The rapid economic growth and the increasing consumption of fossil fuel energy results in the emission of large amounts of NOx to the atmosphere. Approximately 24 million tons of NO were released to the atmosphere from US sources during 1998.3 Titles I and IV of the 1990 Clean Air Act Amendments regulate NOx emissions from major stationary sources. 4 The overall goal of these programs was to achieve NOx reductions of 2 million tons per year below 1980 levels by the year 2000 .

Concern for environmental and health issues coupled to stringent NOx emission standards indicate a need for the development of efficient low-cost NOx abatement technologies. Conventional post-combustion controls include selective catalytic reduction (SCR), 4 selective non-catalytic reduction (SNCR),5, 6 adsorption,7, 8 and scrubbing (absorption).9, 10 The major drawback of conventional systems is the prohibitive cost for treating large volumes of air containing low to moderate concentrations of NOx. In addition, conventional systems generate secondary wastes, often requiring further treatment. The biological removal of NOx from contaminated gas streams is an emerging technology that can be applied to air pollution control in stationary sources. Other new technologies, such as pulse corona introduced plasma11 and pressure swing adsorption (PSA),12 are efficient and more cost-effective than conventional techniques for the removal of higher NOx concentrations, but are still expensive when treating large volumes of gas. Biological processes are alternative costeffective treatment methods. The operation principle is relatively simple and consists generally of passing a contaminated air stream through a porous packed bed on which pollutant-degrading cultures are immobilized. Under optimal conditions, the pollutants can be converted biologically into benign end products, such as water, carbon dioxide, $\mathrm{NO}_{3}{ }^{-}, \mathrm{N}_{2}$ and new biomass.13-16

\section{Sources of NOx}

Nitrogen oxides are released from both natural and anthropogenic sources, as is also often the case for many other different groups of volatile pollutants.17 The production of NOx is in fact more significant in natural sources than in anthropogenic sources, mainly as the result of the activity of nitrogen-consuming microorganisms in soil. Besides, natural NOx generation has recently increased due to the larger worldwide use of fertilizers over the present and recent past decades.

The anthropogenic sources of NOx are motor vehicles (49\%), electric utilities (27\%), other industrial, commercial and residential sources (19\%), and all other activities (5\%) that burn fuels. 3 This shows that anthropogenic sources are generally linked to combustion processes used in either mobile sources or stationary sources. Nitrogen $\left(\mathrm{N}_{2}\right)$ is the most abundant molecule in air, representing $79 \%$ by volume. Therefore, NOx 
appear in exhaust gases from most motor vehicles due to their formation during the combustion of molecular nitrogen from air at high temperatures. NOx are also generated as a result of the combustion of different forms of nitrogen compounds in fossil fuels. During the oxidation of nitrogen gas, nitrogen monoxide is formed first, to be converted subsequently to nitrogen dioxide in the presence of either oxygen or ozone:

$\mathrm{N}_{2}+\mathrm{O}_{2} \longrightarrow 2 \mathrm{NO}$

$2 \mathrm{NO}+\mathrm{O}_{2} \longrightarrow 2 \mathrm{NO}_{2}$

Actually, these are equilibrium reactions in which the concentrations of the products (NOx) will increase whenever the temperature, the oxygen concentration and/or the residence time in the combustion chamber are increased. Nevertheless, if reducing one or several of these three parameters slows down the formation of nitrogen oxides, it sometimes also reduces the combustion efficiency. Moreover, the incomplete combustion of fuel may result in the formation of other undesirable pollutants.

Combustion gas streams typically contain different amounts of oxygen and fluctuate in temperature depending on the post-combustion treatment. Industrial treatment technologies designed for NOx removal from flue gases must be capable of operating under these variable conditions. For example, the flue gas discharged from fuel oil-fired power plants is estimated to contain typically $13 \%$ (v/v) $\mathrm{CO}_{2}, 2 \%(\mathrm{v} / \mathrm{v}) \mathrm{O}_{2}, 500 \mathrm{ppm}$ (v/v) SOx, 100-300 ppm (v/v) NOx, and $\mathrm{N}_{2}$.

Nitrogen oxides as $\mathrm{NO}_{2}$ are also found in some industrial effluents generated during production processes, as in the case of nitric acid plants, but the environmental impact is far less important than for other NOx.

\section{CONVENTIONAL NON-BIOLOGICAL PROCESSES}

The most attractive alternative to limit pollution problems would be to reduce NOx emissions instead of applying specific treatment processes. However, this is not always feasible nor advantageous. For example, lowering the amount of excess air used in combustion processes will reduce the concentration of NOx in the waste gas. Nevertheless, it will also affect the combustion efficiency. Since lowering emission levels during combustion is not always easy, treatment technologies often need to be applied. The most important treatment technologies are described hereafter, focusing mainly on the innovative biological processes.

\section{Selective catalytic reduction (SCR)}

In selective catalytic reduction, a reactant is added to reduce NO to molecular nitrogen. It is usually based on the following reactions between ammonia and NOx at high temperatures. 4

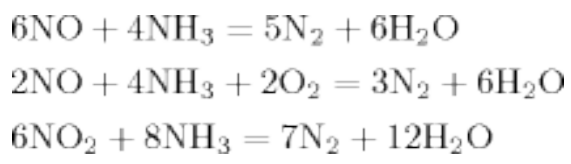

Basically the same reactions occur during selective non-catalytic reduction (SNCR) described in the next section. The difference is that the catalysts, particularly noble 
metal-exchanged zeolites and copper ion-exchanged zeolites, used exclusively in selective catalytic reduction, allow the reaction to proceed at lower temperatures. Different temperatures have been tested in the SCR process, but at lower temperatures, higher amounts of catalysts need to be used. Therefore, reducing the temperature too much may not be cost-effective. However, too high a temperature cannot be applied either since part of the oxygen would be used to oxidize $\mathrm{NH}_{3}$ to $\mathrm{NO}$, resulting in reduced NOx removal. Typically, temperatures between 500 and $750 \mathrm{~K}$ are applied. The major advantage of the catalytic process (SCR) compared with the non-catalytic one (SNCR) is that lower temperatures can be applied while reaching similar treatment efficiencies, thus lowering the operation's costs. However, the use of a, sometimes relatively expensive, catalyst contributes to increased investment costs. SCR is the most widely applied post-combustion NOx control method, but it has two significant problems, which are catalyst deactivation and the presence of unreacted ammonia in the flue gas that can reach $10 \mathrm{ppm}$.

\section{Selective non-catalytic reduction (SNCR)}

The selective non-catalytic reduction process 5,6 involves the injection of a nitrogencontaining compound such as ammonia $\left(\mathrm{NH}_{3}\right)$ or urea $\left(\mathrm{CO}\left(\mathrm{NH}_{2}\right)_{2}\right)$ in a region where the gas temperature is in the range of 1140-1420 K. The temperature window depends upon whether ammonia or urea is used. In this case, NOx are reduced thermally and the reactions take place without the addition of any catalyst. Over this temperature range, ammonia or urea is ionized and reacts with NOx in the presence of oxygen to form molecular nitrogen, carbon dioxide, and water. The equations for the reactions of ammonia with NOx are:

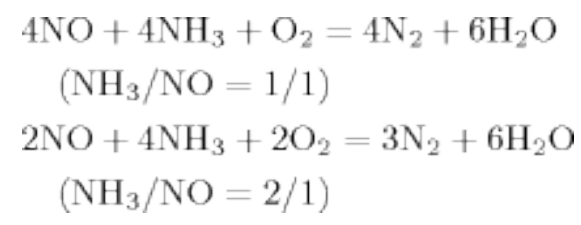

For temperatures between approximately 1140 and $1420 \mathrm{~K}$, the first equation dominates. The higher the temperature, the larger the contribution of the second equation.

The equation for the reaction of urea is:

$\mathrm{CO}\left(\mathrm{NH}_{2}\right)_{2}+2 \mathrm{NO}+0.5 \mathrm{O}_{2}=2 \mathrm{~N}_{2}+\mathrm{CO}_{2}+2 \mathrm{H}_{2} \mathrm{O}$

If the reaction temperature is too low, eg below $1000 \mathrm{~K}$, part of the ammonium will not react and it will appear in the exhaust gas.

\section{Adsorption}

Several decades ago, commercial zeolites (molecular sieves) were found to efficiently remove low concentrations of nitrogen oxides from gas streams.18 The zeolite could effectively adsorb NOx from waste gas streams in a nitric oxide plant. Adsorbed NOx can be recovered as enriched $\mathrm{NOx}$ and $\mathrm{HNO}_{3}$ by regenerating the bed at elevated temperatures with hot air and/or steam. Tests indicated that such a system could be 
incorporated into an existing nitric acid plant, preventing the release of significant quantities of NOx into the atmosphere.

More recently, Wang et al7 investigated the adsorption properties of NO on aluminasupported palladium by simultaneous thermogravimetric-analysis and differential scanning calorimetry (TGA-DSC) in a temperature range of 220-470 K.

With other common adsorbents, such as activated carbon, NO in contaminated waste gases is converted to $\mathrm{NO}_{2}$. Guo et al8 investigated the removal of $\mathrm{NOx}$ by the catalytic oxidation of $\mathrm{NO}$ to $\mathrm{NO}_{2}$ on activated carbons at $30{ }^{\circ} \mathrm{C}$. The results showed that the NO conversion markedly decreases with the rise of gas temperature and with moisture content. To be efficient, this process requires complete de-moisturing of the flue gas prior to the reaction. The CHA process (CHA Corporation, CA, USA) is another treatment system, based on the use of carbon, that removes oxides of nitrogen from small stationary diesel engines. The diesel exhaust is adsorbed onto a moving carbon adsorbent bed. Subsequently, microwaves are utilized to regenerate the carbon adsorbent and reduce the NOx.19

\section{Scrubbing}

A lot of research still needs to be done in order to understand NO removal in wet scrubbers. In general, additives have to be added to the scrubbing system to convert insoluble NO to soluble NOx or to form a complex, which can be removed. Possible NO oxidants are $\mathrm{ClO}_{2}$ or $\mathrm{O}_{3} .10$ However, these additives are quite expensive as well as very dangerous in equipment operating in the gas phase. Therefore, chemical reagents added to the liquid phase have been widely used.9 Kobayashi et al20 investigated the removal of nitrogen oxides using a number of inorganic and organic reagents. Their results showed that strong oxidizing reagents such as $\mathrm{KMnO}_{4}$ and $\mathrm{NaClO}_{2}$ removed $\mathrm{NO}$ efficiently. Chu et al10 used $\mathrm{NaClO}_{2} / \mathrm{NaOH}$ to perform a preliminary test on a semicontinuous spraying sieve tray combined $\mathrm{SO}_{2} / \mathrm{NO}$ removal system and a continuous spraying sieve tray column. The results showed that $\mathrm{NaClO}_{2} / \mathrm{NaOH}$ worked well for the combined $\mathrm{SO}_{2} / \mathrm{NO}$ removal system.

Aqueous solutions of iron chelates have been widely employed to catalyze the absorption of NOx. Demmink and co-workers21 used solutions of ferrous chelates of nitrilotriacetic acid (NTA), ethylenediaminetetraacetic acid (EDTA), hydroxyethylenediaminetriacetic acid (HEDTA), and diethylenetriaminepentaacetic acid (DTPA) to absorb the nitric oxide in a stirred cell reactor. They found that the absorption leads to the formation of stable ferrous NO chelates and that the mass transfer rate greatly affects the absorption rate.

Although these post-combustion controls offer sufficient treatment of nitrogen oxides, the cost is high and products requiring further disposal are often generated.

\section{RECENT BIOLOGICAL TECHNOLOGIES FOR NOX REMOVAL}

There are many different bioprocesses, developed recently, available to control NOx emissions. The major technologies can be classified into different groups: (i) nitrification; (ii) denitrification; (iii) microalgae; (iv) BioDeNOx. 


\section{Nitrification}

Nitrification is the process by which ammonium is oxidized to nitrate, as indicated in Fig 1. This process is carried out by two distinct groups of bacteria: the ammonium oxidizers, which oxidize ammonium to nitrite, and the nitrite oxidizers, which oxidize nitrite to nitrate. Ammonium oxidizers may produce nitric oxide during oxidation of ammonium under particular growth conditions.22-25 Three distinct classes of ammonium oxidizers can be distinguished, as indicated below:

- (1)The lithoautotrophic ammonium oxidizers are all Gram-negative bacteria which transduce the free energy necessary for their metabolism from the oxidation of ammonia to nitrite and obtain the majority of carbon for growth by assimilation of carbon dioxide $\left(\mathrm{CO}_{2}\right)$.

- (2)In heterotrophic nitrification, organic and inorganic nitrogen compounds such as ammonia $\left(\mathrm{NH}_{3}\right)$, and organic nitro-compounds are oxidized to a variety of organic and inorganic nitrogen compounds such as nitrate $\left(\mathrm{NO}_{3}{ }^{-}\right)$, nitrite $\left(\mathrm{NO}_{2}{ }^{-}\right)$, hydroxylamine $\left(\mathrm{NH}_{2} \mathrm{OH}\right)$ and trihydroxamic acids. Heterotrophic nitrification only proceeds when an external organic carbon and energy source is available.

- (3)A third class of nitrifiers includes the anaerobic ammonium oxidizers. They use the so-called 'anammox' process which is the oxidation of ammonium coupled to the reduction of nitrite, yielding molecular $\mathrm{N}_{2}$. It has been shown that this is a biological process although the exact biochemical mechanisms have not been elucidated yet. The dominant organism in the anammox community is a Planctomycete.

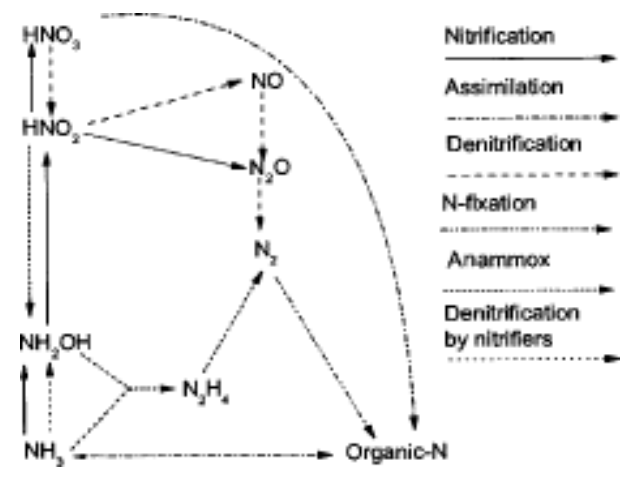

Figure 1.

Simplified nitrogen cycle (reproduced and modified with permission from the copyright holders, IWA).24 Ammonification and nitrification are processes of 'mineralization'. Uptake of ammonia and reductive uptake of nitrate by bacteria are known as 'immobilization', as $\mathrm{N}$ is incorporated into bacterial biomass. Denitrification takes place in low oxygen environments, where $\mathrm{NO}_{3}{ }^{-}$is used as the electron acceptor (oxidant) for the respiration of organic matter. Nitrogen fixation is the process of 'fixing' nitrogen from the atmosphere.

Some promise has been demonstrated in the use of autotrophic nitrifiers to degrade NO,26-31 although most studies have been undertaken at room temperature (Table 1) while thermophilic conditions would be more suitable for the full-scale treatment of most NOx-containing waste gases. Chemoautotrophic organisms are capable of assimilating $\mathrm{CO}_{2}$ as carbon source and obtain energy from inorganic substrates. NO is 
an intermediate metabolite in the nitrification steps that has been shown to produce 200 times more NADH (reduced-nicotinamide adenine dinucleotide) when utilized in Nitrobacter organisms than $\mathrm{NO}_{2}^{-}$. NADH production is directly related to the production of ATP, the cellular energy storage molecule, therefore more energy is available for organisms that produce increased quantities of NADH.30

Table 1. Comparison of the different biological NOx removal methods

\begin{tabular}{|c|c|c|c|c|c|c|c|c|}
\hline Method & Packing & $\begin{array}{l}\mathrm{T}^{\mathrm{a}} \\
\left({ }^{\circ} \mathrm{C}\right)\end{array}$ & $\begin{array}{l}\mathbf{O}_{2} \\
(\%)\end{array}$ & $\begin{array}{l}\text { NO conc } \\
(\mathrm{ppm})\end{array}$ & $\begin{array}{l}\text { EBRT } \\
\text { (min) }\end{array}$ & $\begin{array}{l}\text { Load (g NO } \\
\left.\mathrm{m}^{-3} h^{-1}\right)\end{array}$ & $\begin{array}{l}R E \\
(\%)\end{array}$ & Ref \\
\hline Nitrification & HFMB & $20-55$ & 5 & 100 & $1.9 \mathrm{~s}(5) \mathrm{a}$ & 1.48 & $69-75$ & 37 \\
\hline Nitrification & $\begin{array}{l}\text { Celite, } \\
\text { pumice }\end{array}$ & Room & Air & 100 & 1 & 7.4 & $10-15$ & 29 \\
\hline Nitrification & Slag & Room & Air & 892-1237 & 2 & $2.75-22.4$ & 80 & 31 \\
\hline Nitrification & Biosoil & $20-25$ & Air & 1.6 & 1 & 0.12 & 60 & 35 \\
\hline Denitrification & Compost & $30-45$ & Air & 250 & 1 & 18 & 99 & 51 \\
\hline Denitrification & Compost & 22,37 & - & 500 & 1 & 37 & 90 & 53 \\
\hline Denitrification & Compost & $53-55$ & - & 500 & 1.3 & 28 & 95 & 61 \\
\hline Denitrification & Perlite & $53-55$ & - & 500 & 1.18 & 31 & 94 & 61 \\
\hline Denitrification & Biofoam & $53-55$ & - & 500 & 1.18 & 31 & 85.5 & 61 \\
\hline Denitrification & $\begin{array}{l}\text { Sulfur, } \\
\text { maerlb }\end{array}$ & Room & - & 8978 & 22 & $4.15 \mathrm{mmol} \mathrm{h}^{-1}$ & 10 & 62 \\
\hline Denitrification & $\begin{array}{l}\text { Silicate } \\
\text { pellets }\end{array}$ & 23 & $\begin{array}{l}> \\
17 \%\end{array}$ & 60 & 3 & 0.75 & 75 & 59 \\
\hline Denitrification & $\begin{array}{l}\text { Ceramic } \\
\text { matter }\end{array}$ & 60 & Air & 5 & 2.4 & 0.15 & $60-90$ & 63 \\
\hline Fungi, denitrification & $\begin{array}{l}\text { Silicate } \\
\text { pellets }\end{array}$ & 23 & 21 & 250 & 1 & 18.4 & 93 & 42 \\
\hline Microalgae & & 25 & - & 300 & 26.7 & $22.3 \mathrm{mg} \mathrm{day}^{-1}$ & $50-60$ & 72 \\
\hline $\begin{array}{l}\text { BioDeNOx, } \\
\text { denitrification }\end{array}$ & None & $50-55$ & Air & 250 & & & 60 & 76 \\
\hline
\end{tabular}

- A The gas residence time, calculated as the membrane volume divided by the gas flow rate, was $1.9 \mathrm{~s}$. The overall residence time, calculated as the reactor volume divided by the gas flow rate, was $5.0 \mathrm{~min}$.

- B Mixture of $60 \%$ sulfur and $40 \%$ maerl in volume.

$R E$ : removal efficiency; - : anaerobic.

Davidova et al26 were the first to demonstrate the potential of nitrifying bacteria for NO removal in a gas-phase biofilter packed with porous glass rings. They conducted studies using autotrophic bacteria grown on ammonium in an oxic gas stream. Degradation in that system was rate-limited, requiring long residence times of around $13.7 \mathrm{~min}$ to remove $90 \%$ of NO from a $100 \mathrm{ppm}$ contaminant stream. Examination of the media revealed that the biofilm's appearance was rather sparse and thin. The presence of insufficient biomass for effective bio-oxidation was considered as the cause of the rather inefficient removal. The slow growth of autotrophic bacteria is attributed to the fact that approximately $80 \%$ of the energy generated by autotrophs is used to fix carbon dioxide and the amount of energy gained from the oxidation of ammonia to nitrate is small. 
The above work was further extended using nitrite as a substrate to initially develop and enhance growth of the biofilm.27-29 Trickling biofilters were used to remove NO from contaminated air with different packing materials such as natural red lava rock (1/4 inch pumice), pellets of diatomaceous earth (Celite ${ }^{\circledR}$ R-635) and a very high interfacial area artificial sintered glass (Sirian rings) medium. The measurement of $\mathrm{NO}_{3}{ }^{-}$concentrations in the liquid phase showed that the nitrate levels slowly increased over time and that the recovery of $\mathrm{NO}$ as $\mathrm{NO}_{3}{ }^{-}$exceeded $90 \%$. This definitely confirms that the removal mechanism is nitrification. The systems operated at an EBRT (empty bed residence time) of 1 min exhibited a limited removal efficiency (10-15\%), attributed to mass transfer limitation. However, reduction of the liquid film thickness temporarily yielded up to $100 \%$ improvements in removal efficiency as the aqueous medium drained. The performance did also improve whenever an ultrasonic nebulizer was used to maintain column moisture in lieu of a conventional spray nozzle. The estimated residence time for $90 \%$ removal was reduced from $13.7 \mathrm{~min}$ to $6 \mathrm{~min} .26$ Further studies demonstrated that the high EBRT of 6 min was due to mass-transfer limitation of the poorly soluble nitric oxide and oxygen. Little difference in performance was observed between the Celite and lava rock packings despite the much larger specific surface area of Celite. Clearly the internal pore structure of Celite media was unavailable for effective NO removal because even a thin biofilm covering the openings of the surface pores drastically reduces diffusion of the poorly soluble NO into the interior. Thus, the key to economical biological treatment of NO is to maximize the surface-to-volume ratio that can support the necessary biofilm without clogging of the pores. In a subsequent work, a porous, pyrolyzed carbon-foam structure was used as packing allowing to greatly reduce the mass transfer limitation.30 The pore dimensions could be selected such that the biofilm grew on all surfaces of the fibrous structure, but did not bridge across the openings.

Chou and Lin31 employed an aerobic trickling biofilter using a blast furnace slag as packing material with particulate sizes of $20-40 \mathrm{~mm}$ and a specific surface area of 120 $\mathrm{m}^{2} \mathrm{~m}^{-3}$. Approximately 6 weeks were required to develop a biofilm for NO degradation, using activated sludge as microbial seed, while glucose, yeast powder, phosphate, and $\mathrm{NaHCO}_{3}$ were added as supplementary nutrients. Removal efficiencies of $80 \%$ with a 2 min residence time were demonstrated in the case of gas streams containing 892-1237 ppm NO. Glucose was added as a carbon source supplement to encourage the growth of heterotrophic microorganisms capable of secreting polysaccharides to enhance adhesion of the biofilm to the packing surface. When glucose addition was ceased for 2 weeks, NO removal declined to $48 \%$. This organic carbon deficiency resulted in the detachment of part of the biofilm from the packing surface. Over $90 \%$ of the eliminated NO was converted into nitrate by conversion of the NO to nitrite followed by the nitrification of nitrite to nitrate, suggesting successful removal via nitrification.

In other studies, the biofiltration of $\mathrm{NOx}$, consisting of a mixture of $\mathrm{NO}$ and $\mathrm{NO}_{2}$, was carried out using a laboratory-scale biofilter packed with soil.32-35 The removal efficiency of $\mathrm{NO}_{2}$ by soil was almost $100 \%$, and the removal efficiency of $\mathrm{NO}$ was $60 \%$ on average, and $86 \%$ was the maximum value. By using gamma-irradiated soil as a packing material, $\mathrm{NO}_{2}$ was completely removed mainly by adsorption onto or absorption into the packing material. However, the removal efficiency of NO in the sterilized soil was only $20 \%$, suggesting that NO in soil was removed microbiologically under aerobic conditions. 
Another application of nitrifiers is in the cleaning of polluted air from road tunnels. Robra et al36 isolated microorganisms from natural substratum and from air and dust of road tunnels. They enriched bacteria capable of eliminating low concentrations of CO, $\mathrm{NO}$ and $\mathrm{NO}_{2}$ in a mineral medium in the absence of other nitrogen compounds in a laboratory-scale biotrickling filter packed with light expanded clay aggregates. During this process carboxidotrophic bacteria oxidize $\mathrm{CO}$, and they release energy and $\mathrm{CO}_{2}$ that serves as carbon source for the growth of autotrophic nitrifying bacteria according to the following reaction:

$7 \mathrm{CO}+2.5 \mathrm{O}_{2}+\mathrm{H}_{2} \mathrm{O} \longrightarrow 6 \mathrm{CO}_{2}+\mathrm{CH}_{2} \mathrm{O}+$ Energy

Later, they built a pilot plant to treat polluted air in a road tunnel at the Katschbergtunnel in Carinthia (Austria). The $55 \mathrm{dm}^{3}$ trickling filter exhibited good performance over 2 years of experimentation. At gas residence times ranging from 7.5 to $11 \mathrm{~s}$, maximum removal efficiencies of $90 \% \mathrm{CO}, 15-20 \% \mathrm{NO}, 95 \% \mathrm{NO}_{2}$, and 50 $75 \%$ volatile organic compounds without methane were obtained.

More recently, the feasibility of using a hollow fiber membrane bioreactor (HFMB) as a means to remove NO from combustion gases was also evaluated.37 A detailed description of the basic principles of operation of HFMB for air pollution control in general has been published recently.38 A membrane bioreactor system may overcome many of the limitations of conventional compost biofilters. The HFMB process consists of bundles of microporous hydrophobic hollow fiber membranes, a biofilm containing nitrifying organisms and a nutrient supply. As shown in Fig 2, the synthetic combustion gas $\left(15 \% \mathrm{CO}_{2}, 5 \% \mathrm{O}_{2}, 77 \% \mathrm{~N}_{2}\right)$ containing $\mathrm{NO}$ passes through the lumen of the microporous hydrophobic hollow fiber membranes. The NO gas diffuses through the membrane pores and partitions into a nitrifying biofilm where it is oxidized to $\mathrm{NO}_{3}{ }^{-}$. The hollow fiber membranes serve as a support for the microbial populations and provide a large surface area for NO and oxygen mass transfer. Activated sludge from a wastewater treatment plant was acclimated with an $\mathrm{NH}_{4}{ }^{+}$and $\mathrm{NO}_{2}{ }^{-}$nutrient solution over 2 months and was used to inoculate the HFMB. Over $90 \%$ of the nitrogen was converted to $\mathrm{NO}_{3}{ }^{-}$by nitrification. The HFMB was initially fed $100 \mathrm{ppm} \mathrm{NO}$ at a gas flow rate of $100 \mathrm{~cm}^{3} \mathrm{~min}^{-1}$ for 1 month, and with a liquid recirculation rate of $300 \mathrm{~cm}^{3}$ $\min ^{-1}$. The NO removal rate was $12-14 \mathrm{~g} \mathrm{~m}^{-3}$ day ${ }^{-1}$, corresponding to efficiencies between 34 and $40 \%$. It increased to a maximum of $27 \mathrm{~g} \mathrm{~m}^{-3}$ day $^{-1}$ with $74 \%$ removal efficiency at a recirculation rate of $600 \mathrm{~cm}^{3} \mathrm{~min}^{-1}$ at $20{ }^{\circ} \mathrm{C}$. The NO elimination capacity of the synthetic combustion gas ranged between 24 and $26 \mathrm{~g} \mathrm{~m}^{-3}$ day $^{-1}$ at 20 ${ }^{\circ} \mathrm{C}$. When the temperature was gradually increased from 20 to $30,40,50$, and $55^{\circ} \mathrm{C}$, the performance remained basically constant. The results showed that the gas composition and temperature have no influence on the reactor's performance (Table 1). 


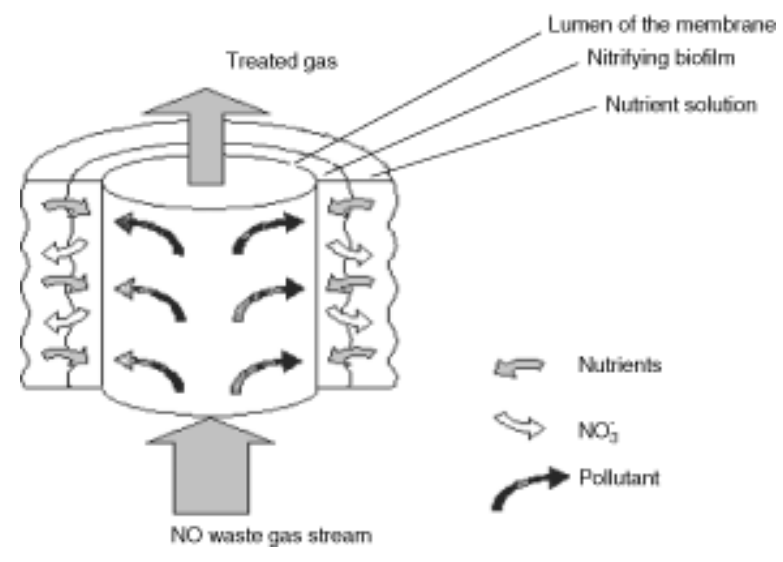

Figure 2.

Conceptual model of the HFMB for waste gas treatment.

\section{Denitrification}

Microbial denitrification is a dissimilatory reductive process via enzyme-catalyzed reactions in which toxic nitrogen oxides are sequentially reduced to environmentally benign nitrogen gas39-42 (Fig 1). A wide variety of organisms are known to denitrify, including some bacteria, fungi and simple eukaryotes.43

\section{Bacteria}

Denitrifying bacteria are ubiquitous in nature and represent indigenous populations in composts and soils. They include a relatively wide variety of physiological and taxonomic groups. Denitrifiers have the ability to reduce oxides of nitrogen when oxygen levels become limited.44 Denitrification is a dissimilatory reductive process that occurs according to the following simplified order:

$\mathrm{NO}_{3}{ }^{-} \longrightarrow \mathrm{NO}_{2}{ }^{-} \longrightarrow \mathrm{NO} \longrightarrow \mathrm{N}_{2} \mathrm{O} \longrightarrow \mathrm{N}_{2}$

Different denitrifying bacteria are thus able to use NOx. Thiobacillus denitrificans, a strict autotroph and facultative anaerobe, may be cultured anaerobically in aqueous phase batch reactors using $\mathrm{NO}$ as a terminal electron acceptor. Thiosulfate can serve as an energy source, $\mathrm{CO}_{2}$ as a carbon source, and ammonium ions as a source of reduced nitrogen.45 Up to $96 \%$ removal was observed with Thiobacillus denitrificans for a gas stream containing $5000 \mathrm{ppm}$ NO. Related studies were performed to check the feasibility to simultaneously remove $\mathrm{SO}_{2}$ and $\mathrm{NOx}$ from cooled flue gas by contact with cultures of the sulfate-reducing bacteria Desulfovibrio desulfuricans, converting $\mathrm{SO}_{2}$ to $\mathrm{H}_{2} \mathrm{~S}$, and Thiobacillus denitrificans, transforming $\mathrm{H}_{2} \mathrm{~S}$ to $\mathrm{SO}_{4}{ }^{2-}$ in cultures-in-series or cocultures in a single contacting stage.46 However, the simultaneous combined $\mathrm{SO}_{2} / \mathrm{NOx}$ removal from flue gas was not technically feasible due to NO inhibition of $\mathrm{SO}_{2}$ reduction in $D$ desulfuricans, nitrate suppression, and oxygen inhibition.

In addition, the same research group found that two heterotrophic denitrifying bacteria, Paracoccus denitrificans and Pseudomonas denitrificans, utilize NO as a terminal electron acceptor, converting it into elemental nitrogen in the presence of succinate, yeast extract, and heat/alkali-pretreated municipal sewage sludge as carbon and energy 
sources.40, 47 Complete removal of $5000 \mathrm{ppm}$ NO from a feed gas sparged into the liquid cultures was observed. All these results suggest that reduction of NO may be a common property of denitrifying bacteria. Potter and colleagues48, 49 used Fourier transform infrared (FTIR) spectroscopy of vapor phase spectra in order to directly monitor the biomimetic reduction of $\mathrm{NO}$ to $\mathrm{N}_{2} \mathrm{O}$ by dithiothreitol in the presence of cyanocobalamin and cobalt-centered porphyrins. Reaction rates were two-fold faster for the cobalt corrin than for the cobalt-centered porphyrins. The stoichiometry showed loss of two NO molecules per molecule of $\mathrm{N}_{2} \mathrm{O}$ generated.

Denitrifiers are typically facultative organotrophs, which utilize organic carbon as an energy source.50 Some authors have observed denitrification in compost-biofilters.5155 At low NO concentrations, the quantity of compost used in these studies provided adequate carbon and energy sources for removal and degradation. However, at higher NO concentrations, the amount of available carbon substrates became limited and the addition of an exogenous carbon source was required to maintain efficient NO reduction. As high as $90 \%$ removal efficiency was observed for a 500 ppm NO gas stream at an EBRT of $1.3 \mathrm{~min}$ when treated in the presence of a phosphate buffer containing either lactate or dextrose compared with $20 \%$ removal in a nonsupplemented biofilter.53, 56-58 Lactate, glucose, dextrose and molasses, as well as labile organic material inherent in compost, have all been used as carbon sources in NO denitrifying systems. Several volatile organic compounds can also be used as carbon and energy sources, and denitrification activity has been observed in a superficially aerobic toluene-treating biofilter.59 In such a system, the presence of a thick biofilm creating anaerobic underlayers allowed denitrification to nitrogen gas. Removal efficiencies of $75 \%$ of $60 \mathrm{ppm}$ NO streams were reported for an EBRT of 6 min. Also, the removal of NO from a simulated wet-scrubbed combustion gas was investigated with different packing materials (compost, perlite and biofoam). The results showed that all three packing materials performed well, reaching more than 85\% NO removal at EBRT of 70-80 s. The compost performed better than the other packings at shorter EBRT of 13-45 s. However, inert carrier materials such as perlite and biofoam are known to offer long term stability and reduced back-pressure compared with organic filter beds as compost.60 The experimental data suggest that the compost, perlite and biofoam systems, subject to further optimization, offer potential for the biological removal of NOx from gas streams.61

Another system that has been investigated is based on the pre-concentration of low concentrations of NO at a high volumic flow onto activated carbon (Pica NC 60), followed by the thermal desorption of NOx and a biological denitrification treatment of the thermically desorbed gas.62 The NOx flow can be purified by $T$ denitrificans grown on a sulfur-maerl support with a superficial gas velocity of $0.5 \mathrm{~m} \mathrm{~h}^{-1}$. The NOx inlet concentration was $10000-20000 \mathrm{mg} \mathrm{m}^{-3}$ and the EBRT was $22 \mathrm{~min}$.

Most of the research studies published on biological NOx removal and described above were performed under mesophilic conditions, which may not be cost-effective at fullscale since NOx-polluted air is often released at rather high temperatures. Lebedeva and co-workers63 isolated 82 strains of thermophilic NO-consuming bacteria in sediment samples from hot springs in the Kronot reserve (Kamchatka), corroded matter from steel pipes of the heating system in Moscow, and soils of the southern bioclimatic belt in Russia (chestnut, white alkali soils). Three of them, belonging to the genus Bacillus and growing at $60{ }^{\circ} \mathrm{C}$ were chosen for further investigation. Two of these organisms were 
isolated from the municipal heating system, and the other one, the most active strain, came from the precipitate of a thermal spring. The latter was identified as Bacillus stearothermophilus strain INMI 50. Cells of this strain immobilized on a ceramic support demonstrated a high NO uptake in a $4 \mathrm{dm}^{3}$ bioreactor. Around $60-90 \%$ of NO was removed at $60{ }^{\circ} \mathrm{C}$ over 6 months of continuous bioreactor operation with inlet concentrations of $5 \mathrm{ppm}$ and a gas flow rate of $100 \mathrm{dm}^{3} \mathrm{~h}^{-1}$ (Table 1). Either glycerol or 1,2-propanediol was used as carbon and energy source.

\section{Fungi}

Studies with filamentous fungi, investigating their capacity to degrade volatile organic and inorganic pollutants and their application to air pollution control in gas-phase bioreactors, are quite recent areas of research.64 For over a century, denitrification and ammonification had been considered as processes exclusively found in prokaryotes, until denitrification was observed in the filamentous fungus Fusarium oxysporum65 and in other fungi66 which were long thought to be strictly aerobic.

Many fungi related to the genus Fusarium and its teleomorphs were shown to be capable of reducing nitrite anaerobically and to form $\mathrm{NO}, \mathrm{N}_{2} \mathrm{O}$, and/or $\mathrm{N}_{2}$. Several strains could reduce nitrate as well. $\mathrm{N}_{2} \mathrm{O}$ was the major product of the reduction of nitrate or nitrite. Several fungi could also form nitrogen. When radiolabeled nitrite was used as substrate for the $\mathrm{N}_{2}$-forming denitrification, ${ }^{15} \mathrm{~N}_{2} \mathrm{O},{ }^{15} \mathrm{NO}$, and ${ }^{14} \mathrm{~N}^{15} \mathrm{~N}$ were obtained as the products. These results demonstrated that many fungi have denitrifying abilities. Fungal systems maybe an attractive alternative to conventional treatment processes for the degradation of nitrogen compounds.66, 67

Denitrification is catalyzed by distinct enzyme species: $\mathrm{NO}_{3}{ }^{-}$reductase (Nar), $\mathrm{NO}_{2}{ }^{-}$ reductase (Nir), nitric oxide reductase (Nor), and nitrous oxide reductase $\left(\mathrm{N}_{2} \mathrm{Or}\right)$ and involves $\mathrm{NO}_{2}{ }^{-}$, $\mathrm{NO}$, and $\mathrm{N}_{2} \mathrm{O}$ as intermediate compounds (Fig 3). Denitrification is part of the bioenergetic metabolism of microbial cells in which these nitrogen oxides serve as terminal electron acceptors for the respiratory chain instead of oxygen.

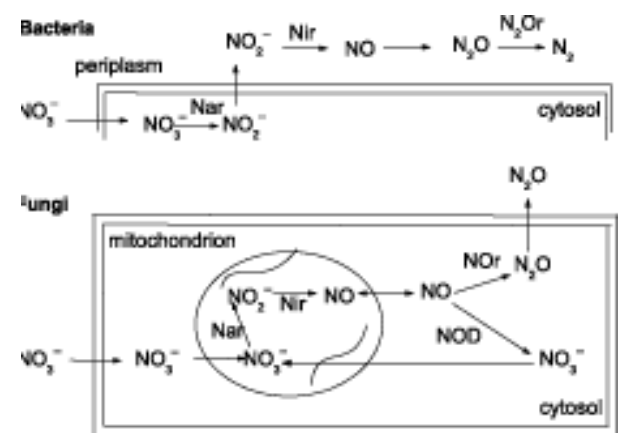

Figure 3.

Comparison of the denitrifying systems of bacteria and fungi. Nar, Nitrate reductase; Nir, nitrite reductase; NOr, nitric oxide reductase; $\mathrm{N}_{2} \mathrm{Or}$, nitrous oxide reductase.

The enzymes responsible for fungal denitrification have been isolated in Fusarium oxysporum. The unique nitrate/nitrite-inducible cytochrome $\mathrm{P}-450$ ( $\mathrm{P}-450_{\mathrm{dNIR}}$ ) was discovered. It was expected that the fungus would be capable of metabolizing nitrate 
dissimilatively. The end product of denitrification by $F$ oxysporum is $\mathrm{N}_{2} \mathrm{O}$. This indicates that the organism lacks an $\mathrm{N}_{2} \mathrm{O}$ reductase. Comparison of the cell growth during denitrification indicated that the dissimilatory reduction of nitrate to nitrite is an energetically favorable process in $F$ oxysporum. However, further reduction of nitrite to $\mathrm{N}_{2} \mathrm{O}$ might be energy-exhausting and may function as a detoxification mechanism. This is unlike bacterial systems, which use a membrane-bound electron transport chain. Studies using Fusarium solani, Cylindrocarpon tonkinse, and Chaetomium sp have reported nitrogen as the end product of denitrification, but the enzymes responsible for $\mathrm{N}_{2} \mathrm{O}$ respiration still need to be determined.65, 68

Fungi such as Aspergillus sp Alternaria sp, F solani, Fusarium verticillioides, Fusarium dimerum, and Fusarium javanicum have proved also to exhibit denitrifying abilities in aerobic environments. Denitrification in $F$ oxysporum is an oxygen-inhibited process. The effects of oxygen on fungal denitrification are still under investigation.43

A toluene-degrading fungal bioreactor containing the black, dimorphic fungus Exophiala lecanii-corni was proven to aerobically remove NO from a contaminated gas stream, using toluene as a sole carbon and energy source.42 The fungal bioreactor removed 93\% $\mathrm{NO}$ at an inlet concentration of $250 \mathrm{ppm}$ and an EBRT of $1 \mathrm{~min}$, corresponding to an inlet loading rate of $17.22 \mathrm{~g}-\mathrm{NO} \mathrm{m} \mathrm{m}^{-3} \mathrm{~h}^{-1}$ when simultaneously supplied with 90 g-toluene $\mathrm{m}^{-3} \mathrm{~h}^{-1}$. Also, it was observed that the removal of NO may be inhibited by the presence of high $\mathrm{NH}_{4}{ }^{+}$concentrations in the fungal biofilm.

\section{Microalgae}

A marine microalga, strain NOA-113, cultivated in a long tubular photobioreactor was found to simultaneously eliminate nitric oxide (NO) and carbon dioxide $\left(\mathrm{CO}_{2}\right)$ from a model flue gas.69 About $40 \mathrm{mg}$ of $\mathrm{NO}$ and $3.5 \mathrm{~g}$ of $\mathrm{CO}_{2}$ were eliminated per day in a 4 $\mathrm{dm}^{3}$ reactor column with aeration of $300 \mathrm{ppm}(\mathrm{v} / \mathrm{v}) \mathrm{NO}$ and $15 \%(\mathrm{v} / \mathrm{v}) \mathrm{CO}_{2}$ in $\mathrm{N}_{2}$ at a rate of $150 \mathrm{~cm}^{3} \mathrm{~min}^{-1}$. The researchers used this reactor system to evaluate NO elimination by microalgae and to investigate the effects of the NO concentration, gas flow rate, and light conditions on NO elimination.

In order to thoroughly understand the process of NO removal from flue gases by an algal culture, a bioreactor system using the unicellular microalga Dunaliella tertiolecta was designed.70 When nitric oxide, the main component of NOx in the flue gas, was supplied at concentrations ranging from 25 to $500 \mathrm{ppm}$ to the algal culture in a $2 \mathrm{~m}$ column-bioreactor in the light, about $65 \%$ of the NO was removed. Under these conditions, cell growth was not affected by the concentration of the NO supplied, and about $1.6 \% \mathrm{O}_{2}$ was constantly evolved by photosynthesis. About $30 \%$ of the NO was removed in a solution without cells, at $2 \% \mathrm{O}_{2}$, in which case the $\mathrm{NO}$ was probably photochemically oxidized by $\mathrm{Fe}^{3+}$ present in the medium. However, in cell cultures without $\mathrm{Fe}^{3+}, 65 \%$ NO removal was achieved. In the dark, on the other hand, the rate of NO removal was governed by the amount of oxygen supplied in the inlet gas, ie the obtention of an NO removal rate similar to that achieved in the light required the presence of oxygen at $2 \%$ or more, and NO removal did not occur without the supply of oxygen. It was found that the presence of both algal cells and oxygen is important in the reactor system. The following hypothesis regarding NO removal kinetics was proposed: NO in the gas is first dissolved in the aqueous phase, after which it is oxidized and assimilated by the algal cells as illustrated through the following reactions. 


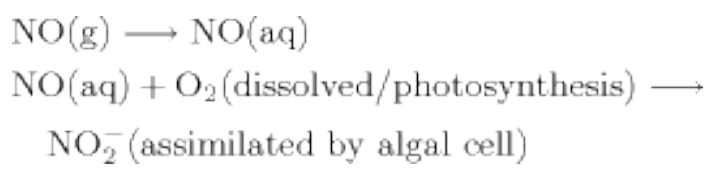

The results of investigations under various culture conditions indicate that the dissolution of NO in the aqueous phase is the rate-limiting step in this reactor system.

Also, the same research group used the green alga Dunaliella tertiolecta cultivated in a bubble column and airlift reactors to remove NO.71 The gas-liquid contact area was increased by reducing the bubble size and thereby ensuring a higher NO dissolution rate. The results showed that NO removal was enhanced by increasing the dissolution of NO in water. In addition, the dissolved oxygen can also improve the NO removal. The highest level of NO removal, 96\%, was achieved with a countercurrent-flow type airlift reactor aerated with small bubbles.

The uptake pathway of NO was investigated in a bubble column-type bioreactor.72 It was found that little NO was oxidized in the medium before its uptake by algal cells and that NO mostly permeated directly into the cells by diffusion, based on the mass balance calculations for nitrogen and on the change in nitrate and nitrite concentrations in the medium in batch culture. NO taken up in the algal cells was then preferentially utilized as a nitrogen source for cell growth rather than nitrate, which was one of the nitrogen sources contained in the algal medium. The contents of total lipids, starch, and protein in the cells cultivated with NO were similar to those in cells cultivated without NO. Therefore, this algal system is useful for the continuous NO removal and production of algal biomass using $\mathrm{NO}$ as a nitrogen source. It is thought that a part of the nitrogen contained in the proteins originates from NO. Continuous NO removal by the $D$ tertiolecta culture was possible under stable conditions for over 15 days in the presence of light.

\section{BioDeNOx}

BioDeNOx is an integrated physicochemical and biological NOx removal technique, as indicated in Fig 4. A chelating agent, $\mathrm{Fe}^{(\mathrm{II})}$ (EDTA), is used to improve the NOx absorption into the scrubbing liquid, thereby obtaining high removal efficiencies.73, 74 The NOx in the scrubbing liquid is subsequently converted into harmless nitrogen using denitrifying bacteria, with ethanol as electron donor. At the same time, the $\mathrm{Fe}^{(\mathrm{II})}$ (EDTA) solution is regenerated.75-77 Using this method, removal efficiencies of more than $80 \%$ can be achieved in such a bioscrubber. The BioDeNOx process is based on the following four reactions:76

- (1)Wet absorption and complexation of NOx by Fe ${ }^{(\mathrm{II})}$ (EDTA). The reaction rate is very fast, which enhances the mass transfer rate of NOx.

$$
\mathrm{Fe}^{(\amalg I)}(\mathrm{EDTA})+\mathrm{NO} \longrightarrow \mathrm{Fe}^{(\Pi)}(\mathrm{EDTA})-\mathrm{NO}
$$

- (2)Oxidation of $\mathrm{Fe}^{(\mathrm{II})}$ (EDTA) to $\mathrm{Fe}^{(\mathrm{III})}$ (EDTA) by oxygen in the flue gas. This reaction should not occur as it consumes the $\mathrm{Fe}^{\text {(II) }}$ (EDTA) which is needed for NO absorption. 


$$
\begin{aligned}
& 2 \mathrm{Fe}^{(\mathrm{II})}(\mathrm{EDTA})+1 / 2 \mathrm{O}_{2}+2 \mathrm{H}^{+} \longrightarrow \\
& 2 \mathrm{Fe}^{(\mathrm{III})}(\text { EDTA })+\mathrm{H}_{2} \mathrm{O}
\end{aligned}
$$

- (3)Biological reduction of $\mathrm{NOx}$ to $\mathrm{N}_{2}$ by denitrifying bacteria, with ethanol as electron donor.

$$
\begin{gathered}
6 \mathrm{Fe}^{(\mathrm{II})}(\mathrm{EDTA})-\mathrm{NO}+\mathrm{C}_{2} \mathrm{H}_{5} \mathrm{OH} \longrightarrow 2 \mathrm{HCO}_{3}^{-} \\
+2 \mathrm{H}^{+}+3 \mathrm{~N}_{2}+\mathrm{H}_{2} \mathrm{O}+6 \mathrm{Fe}^{(\mathrm{II})}(\text { EDTA })
\end{gathered}
$$

- (4)Regeneration of $\mathrm{Fe}^{(\mathrm{II})}$ (EDTA) by reduction of $\mathrm{Fe}^{\text {(III) }}$ (EDTA) with ethanol as electron donor.

$$
\begin{gathered}
12 \mathrm{Fe}^{(\mathrm{III})}(\mathrm{EDTA})+\mathrm{C}_{2} \mathrm{H}_{5} \mathrm{OH}+5 \mathrm{H}_{2} \mathrm{O} \longrightarrow \\
2 \mathrm{HCO}_{3}^{-}+12 \mathrm{Fe}^{(\mathrm{II})}(\text { EDTA })+14 \mathrm{H}^{+}
\end{gathered}
$$

The first two reactions take place in the scrubber, this enhances the mass transfer and overcomes limitation problems that other biological treatment processes usually meet. The other two microbial reactions denitrify the $\mathrm{NO}$ to $\mathrm{N}_{2}$ and regenerate the chelating agent $\mathrm{Fe}^{(\mathrm{II})}$ (EDTA) for NO absorption. These two microbial reactions compete for the electron flow.

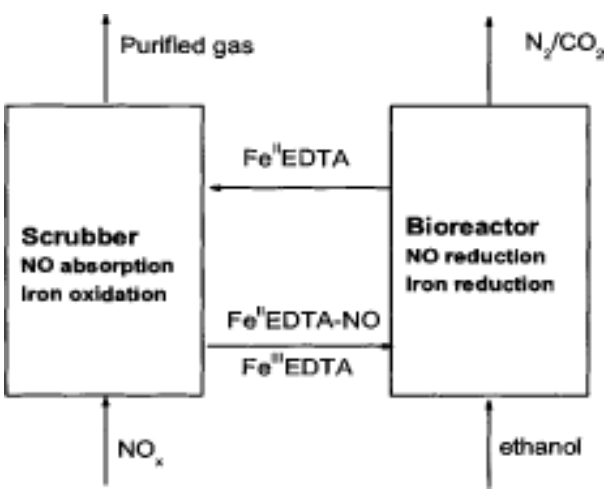

\section{Figure 4.}

Schematic principle of BioDeNOx.

The core processes of the biological regeneration of $\mathrm{Fe}^{(\mathrm{II})}$ (EDTA) have been investigated.78 The reduction of $\mathrm{NO}$ to $\mathrm{N}_{2}$ was found to be catalyzed biologically. The NO reduction follows first order kinetics with respect to the NO/nitrosyl concentration. $\mathrm{Fe}^{(\mathrm{II})}$ (EDTA) serves as electron donor for NO reduction and simultaneously enhances the NO solubility in the water phase. This implies that the redox cycling of $\mathrm{Fe}^{(\mathrm{II})}$ (EDTA) plays an important role in the biological denitrification process. However, continuous reactor experiments demonstrated that the iron reduction capacity rather than the denitrification capacity was limiting the load applicable to the bioreactor. When treating a flue gas containing 3.3\% $\mathrm{O}_{2}$ and $500 \mathrm{ppm} \mathrm{NO}$, approximately $90 \%$ of the electron flow was used for $\mathrm{Fe}^{(\mathrm{III})}$ (EDTA) reduction and only $10 \%$ for NO reduction. Batch experiments strongly suggest that the reduction of EDTA-chelated $\mathrm{Fe}^{(\mathrm{III})}$ is not a direct enzymatic conversion, but rather an indirect nonenzymatic reaction. The redox couple $\mathrm{S}^{0} / \mathrm{S}^{2-}$ plays an important role in the electron transfer between the bacteria and $\mathrm{Fe}^{(\mathrm{III})}(\mathrm{EDTA})$. The redox couple sulfide/elemental sulfur accelerates the electron 
transfer between the bacteria and $\mathrm{Fe}^{(\mathrm{III})}$ (EDTA). Thus, $\mathrm{Fe}^{(\mathrm{III})}$ (EDTA) reduction is most likely a nonenzymatic conversion.

Research was recently done on the kinetics of the oxidation of $\mathrm{Fe}^{(\mathrm{II})}$ (EDTA) under typical BioDeNOx conditions (temperature $=329 \mathrm{~K},\left[\mathrm{Fe}^{(\mathrm{II})}(\right.$ EDTA) $]=50 \mathrm{~mol} \mathrm{~m}^{-3}$ ), on the influence of the $\mathrm{pH}$ on the oxidation rate in the range $5-8$, and on the influence of typical BioDeNOx components, ie $\mathrm{NaCl}$ and biomass.79 The results showed that the oxidation of $\mathrm{Fe}^{(\mathrm{II})}$ (EDTA) is not influenced by the $\mathrm{pH}$ of the solution in the range of 5-8 under the experimental conditions of that study. Moreover, the addition of salt seems to have some positive effect on the reaction kinetics at high $\mathrm{NaCl}$ concentrations $(>10 \mathrm{~kg}$ $\mathrm{m}^{-3}$ ). The presence of bacteria changed the absorption profile of oxygen, influencing the physical characteristics of the solution.

Recently, van der Maas et al80 explored the full denitrification pathway of reduction of nitrogen oxide analogs, ie the reduction of $\mathrm{NO}_{3}{ }^{-}, \mathrm{NO}_{2}{ }^{-}$, and $\mathrm{NO}$ via $\mathrm{N}_{2} \mathrm{O}$ to $\mathrm{N}_{2}$, in aqueous $\mathrm{Fe}^{(\mathrm{II})}$ EDTA solutions. They used biomass from a wastewater treatment plant to show that in aqueous solutions of $\mathrm{Fe}^{(\mathrm{II})}$ EDTA, denitrification is accompanied by the biological reduction of $\mathrm{Fe}^{(\mathrm{III})}$ to $\mathrm{Fe}^{(\mathrm{II})}$. Ethanol, acetate, and methanol are suitable electron donors. Moreover, $\mathrm{Fe}^{(\mathrm{II})}$ EDTA can also serve as electron donor for the chemical reduction of nitrite to $\mathrm{NO}$ and for the biological reduction of $\mathrm{NO}$ to $\mathrm{N}_{2}$ via $\mathrm{N}_{2} \mathrm{O}$. They suggested that the pathway of full denitrification in aqueous $\mathrm{Fe}^{(\mathrm{II})}$ EDTA solution involves both biological and chemical reduction steps with $\mathrm{Fe}^{(\mathrm{II})}$ EDTA as an electronmediating compound. Also, they found that the free uncomplexed EDTA strongly inhibits the biological denitrification activity. This requires an excess of divalent cations to guarantee denitrification in aqueous $\mathrm{Fe}^{(\mathrm{II})}$ EDTA solutions.

\section{CONCLUSIONS}

The different biological NOx removal methods are compared in Table 1. The studies summarized in that table demonstrate that the biological removal of NOx is a viable technology.

Denitrifying biofilters can be an effective NO control technique. However, the low oxygen requirements and the need for the addition of exogenous carbon and energy sources limits the cost-effectiveness of these systems.

In the case of autotrophic systems, chemoautotrophic organisms are capable of fixing $\mathrm{CO}_{2}$ as carbon source and obtain energy from inorganic substrates. Although high removal efficiencies can be achieved, it requires relatively long residence times of 6-12 min. This is likely caused by the NO mass transfer limitation and the slow, insufficient biomass growth. Because of the high Henry's constant of $\mathrm{NO}\left(K_{\mathrm{H}}=0.0019\right.$ mole fraction $\mathrm{atm}^{-1}$ ), the BioDeNOx technology could be a good solution to this problem. This process separates the removal into a scrubbing step and a biodegradation step.

Fungal bioreactors can achieve high NO removal efficiencies with relatively short residence times of only 1 min compared with bacterial biofiltration systems. However, the mechanisms by which fungi utilize NO are not yet well understood. An alternative carbon source needs to be found since the NO waste gas stream does not necessarily contain any volatile organic compound such as toluene or other carbon sources. Moreover, the performance of fungal bioreactors under typical NO waste gas stream 
operating conditions, ie high temperature and low oxygen concentrations, needs to be evaluated.

Although these biological methods show promising results for the treatment of NOcontaminated gas streams, further investigations will be required regarding, among others, the following aspects:

- Investigation of the kinetics of biodegration of NOx in different bioreactors.

- Comparison of the performance of different kinds of bioreactors (biofilter, fungal bioreactor, hollow fiber membrane bioreactor, photobioreactor, bubblecolumn-type bioreactor) and optimization of the reactor design (packing material, etc).

- Optimization of operation parameters for the different systems, as, for example, the temperature, since its fluctuation beyond the optimal temperature range of the microbes can decrease their activity and even kill them. The isolation and study of thermophilic NO-consuming microorganisms would be of interest. Most of the current research considered operation at room temperature, which does not reflect the potential full-scale application. Although many flue gases are scrubbed with a water/limestone slurry to reduce sulfur dioxide emissions, gases exiting the scrubbers typically exhibit temperatures between 50 and $60{ }^{\circ} \mathrm{C}$. It is important to find NO-consuming microorganisms active in such temperature range.

- Biological removal in concert with other control techniques.

- Since the flue gas streams can contain up to 8\% oxygen and oxygen may inhibit the removal of NOx compounds by denitrifying bacteria, the influence of oxygen on the NO removal ability needs to be further investigated in such organisms.

- The presence of $\mathrm{CO}_{2}, \mathrm{SO}_{2}$, and heavy metals such as $\mathrm{Hg}$ or $\mathrm{Cd}$ in the flue gas may affect the growth of microorganisms. Such effect needs to be studied.

- For BioDeNOx, it is worth studying the efficiency of other alternative electron donors such as $\mathrm{H}_{2}$, besides ethanol, and other cheap complex chelating agents. In addition, for some systems which require external carbon sources, cheap alternatives are also important.

- The mechanisms by which microorganisms utilize NOx need to be understood. The application of culture-independent molecular biological techniques provides new insights into biodegradation and offers new opportunities to better understand the dynamics of microbial communities. Advanced molecular techniques as FISH (fluorescent in-situ hybridization) and PCR (polymerase chain reaction) can be used to detect and enumerate the target bacteria that are directly related to the degradation of NOx. Also, 16S rDNA, DGGE, T-REFLP enable the changes in the bacterial community to be monitored in detail.

Overall, microbial reduction of $\mathrm{NO}$ (and $\mathrm{NO}_{2}$ ) merits further study, as a potential means of removal of oxides of nitrogen (NOx). It certainly offers promise as a cost-effective novel alternative treatment method. 


\section{Acknowledgements}

The research work of Yaomin Jin at the University of La Coruña is financially supported through a fellowship of the Agencia Española de Cooperación Internacional (AECI) and the Spanish Ministry of Foreign Affairs.

\section{REFERENCES}

- Kurvits $\mathrm{T}$ and Marta T, Agricultural $\mathrm{NH}_{3}$ and $\mathrm{NOx}$ emissions in Canada. Environ Pollut 102: 187-194 (1998).

- 2Fawler D, Fertilising the atmosphere with fixed nitrogen, the roles of fossil combustion and agriculture. Institute of Terrestrial Ecology, Edinburgh Research Station. The 22nd Macaulay Lecture, May 14th (1998).

- $\quad 3 U S$ EPA, National air pollutant emission trends, 1900-1998. Environmental Protection Agency, Office of Air Quality Planning and Standards, Research Triangle Park, NC, USA, EPA-454/R-00-002, March (2000).

- 4Bradford M, Grover $R$ and Paul P, Controlling NOx emissions: part 1. Chem Eng Prog 98: 42-46 (2002).

- 5Bradford M, Grover R and Paul P, Controlling NOx emissions: part 2. Chem Eng Prog 98: 38-42 (2002).

- 6Wendt JOL, Linak WP, Groff PW and Srivastava RK, Hybrid SNCR-SCR technologies for NOx control: modeling and experiment. AIChE J 47: 2603-2617 (2001).

- 7Wang CB, Yeh TF and Lin HK, Nitric oxide adsorption and desorption on alumina supported palladium. J Hazard Mater 92: 241-251 (2002).

- 8Guo Z, Xie Y, Hong I and Kim J, Catalytic oxidation of $\mathrm{NO}$ to $\mathrm{NO}_{2}$ on activated carbon. Energy Conv Manag 42: 2005-2018 (2001).

- 9Pham EK and Chang SG, Removal of NO from flue gases by absorption to an iron(II) thiochelate complex and subsequent reduction to ammonia. Nature 369: 139141 (1994).

- 10Chu H, Chien TW and Twu BW, The absorption kinetics of $\mathrm{NO}$ in $\mathrm{NaClO}_{2} / \mathrm{NaOH}$ solutions. J Hazard Mater 84: 241-252 (2001).

- 11Yan P, Fujiwara M, Zhou Y and Ishida M, Investigation on luminescence and NOx removal by pulse corona discharges. J Electrost 51-52: 266-271 (2001).

- 12Izumi J, Yasutake A, Tomonaga N, Tsutaya H and Oka N, Development on high performance gas separation process using gas adsorption. Technical Review 39: 6-10 (2002).

- 13Stepanov AL and Krpela TK, Microbial basis for the biotechnological removal of nitrogen oxides from flue gases. Biotechnol Appl Biochem 25: 97-104 (1997).

- 14Schroeder ED, Trends in application of gas-phase bioreactors. Re/Views in Environmental Science and Bio/Technology 1: 65-74 (2002).

- 15Boswell J, Understand the capabilities of bio-oxidation. Chem Eng Prog 98: 48-53 (2001).

- 16Devinny JS, Deshusses MA and Webster TS, Biofiltration for Air Pollution Control. Lewis, Boca Raton, New York, $p 1$ (1999).

- 17Kennes $C$ and Veiga MC, Fundamentals of air pollution, in Bioreactors for Waste Gas Treatment, ed by KennesC and VeigaMC. Kluwer Academic Publishers, Dordrecht, The Netherlands, pp 3-15 (2001). 
- 18Sundaresan BB, Harding CI, May FP and Hendrickson ER, Adsorption of nitrogen oxides from waste gas. Environ Sci Technol 1: 151-156 (1967).

- 19California Air Resources Board, Technology briefs posted at the Innovative Clean Air Technology Program. www.arb.ca.gov/research/icat/projects.htm (2000) [accessed 1 December 2004].

- 20Kobayashi H, Takezawa $N$ and Niki T, Removal of nitrogen oxides with aqueous solutions of inorganic and organic reagents. Environ Sci Technol 11: 190-192 (1977).

- 21Demmink JF, van Gils ICF and Beenackers AACM, Absorption of nitric oxide into aqueous solutions of ferrous chelates accompanied by instantaneous reaction. Ind Eng Chem Res 36: 4914-4927 (1997).

- 22Verstraete $W$ and Alexander $M$, Heterotrophic nitrification in samples of natural ecosystems. Environ Sci Technol 7: 39-42 (1973).

- 23Jetten MSM, Logemann S, Muyzer Gerard, Robertson LA, de Vries S, van Loosdrecht MCM and Kuenen JG, Novel principles in the microbial conversion of nitrogen compounds: development on high performance gas separation process using gas adsorption. Antonie van Leeuwenhoek 71: 75-93 (1997).

- 24van Loosdrecht MCM and Jetten MSM, Microbiological conversions in nitrogen removal. Water Sci Technol 38: 1-7 (1998).

- 25Beaumont HJE, Hommes, NG, Sayavedra-Soto, LA, Arp, DJ, Arciero, DM, Hooper, AB, Westerhoff, HV and Van Spanning, RJM, Nitrite reductase of Nitrosomonas europaea is not essential for production of gaseous nitrogen oxides and confers tolerance to nitrite. J Bacteriol 184: 2557-2560 (2002).

- 26Davidova YB, Schroeder ED and Chang DPY, Biofiltration of nitric oxide. Proceedings, 90th Annual Meeting, Air and Waste Management Association, Pittsburgh, PA, June 18-22 (1997).

- 27Hudepohl NJ, Schroeder ED and Chang DPY, Oxidation of nitric oxide in a biofilter. Proceedings, 91st Annual Meeting, Air and Waste Management Association, San Diego, CA, June 14-18 (1998).

- 28Nascimento DM, Davidova Y, du Plessis CA, Schroeder ED and Chang DPY, Biofilter technology for NOx control. Final Report, Project 96-304. California Air Resources Board Research Division, Sacramento, CA (1999).

- 29Nascimento DM, Hudepohl NJ, Schroeder ED and Chang DPY, Bio-oxidation of nitric oxide in a nitrifying aerobic filter. Proceedings, 93 ${ }^{\text {rd }}$ Annual Meeting, Air and Waste Management Association, Salt Lake City, Utah, June 18-22 (2000).

- 30Catton K, Hershman L, Chen JM, Schroeder ED and Chang DPY, Aerobic removal of NO on carbon foam packings. Proceedings, 95 th Annual Meeting, Air and Waste Management Association, Baltimore, MD, June 23-27 (2002).

- 31Chou MS and Lin JH, Biotrickling filtration of nitric oxide. J Air Waste Manage Assoc 50: 502-508 (2000).

- 32Lukow $T$ and Diekmann H, Aerobic denitrification by a newly isolated heterotrophic bacterium strain TL1. Biotechnol Lett 19: 1157-1159 (1997).

- 33Yani M, Hirai M and Shoda M, Enhancement of ammonia removal in peat biofilter seeded with enriched nitrifying bacteria. Environ Technol 21: 1199-1204 (2000).

- 34Kim NJ, Hirai M and Shoda M, Comparison of organic and inorganic packing materials in the removal of ammonia gas in biofilters. J Hazard Mater 72: 77-90 (2000).

- 35Okuno K, Hirai M, Sugiyama M, Haruta K and Shoda M, Microbial removal of nitrogen monoxide (NO) under aerobic conditions. Biotechnol Lett 22: 77-79 (2000). 
- 36Robra KH, Wellacher $M$, Kirchmeir $F$, Leistentritt $R$ and Pucher $K$, Abluftreinigung fur straßentunnel und tiefgaragen durch carboxidotrophe mischpopulationen. Biological Waste Gas Cleaning, Proceedings of an International Symposium, Maastricht, The Netherlands, April 28-29 (1997).

- 37Min KN, Ergas SJ and Harrison JM, Hollow-fiber membrane bioreactor for nitric oxide removal. Environ Eng Sci 19: 575-583 (2002).

- 38Ergas SJ, Membrane bioreactors, in Bioreactors for Waste Gas Treatment, ed by KennesC and VeigaMC. Kluwer Academic Publishers, Dordrecht, The Netherlands, pp 163-177 (2001).

- 39Kalkowski I and Conrad R, Metabolism of nitric-oxide in denitrifying Pseudomonas-aeruginosa and nitrate-respiring Bacillus-cereus. FEMS Microbiol Lett 82: 107-111 (1991).

- 40Shanmugasundram R, Lee CM and Sublette KL, Reduction of nitric oxide by denitrifying bacteria. Appl Biochem Biotechnol 39-40: 727-737 (1993).

- $41 Y e$ RW, Averill BA and Tiedje JM, Denitrification-production and consumption of nitric-oxide. Appl Environ Microbiol 60: 1053-1058 (1994).

- 42Woertz JR, Kinney KA and Szaniszlo PJ, A fungal vapor phase bioreactor for the removal of nitric oxide from waste gas streams. J Air Waste Manage Assoc 51: 895-902 (2001).

- 43Zumft WG, Cell biology and molecular basis of denitrification. Microbiol Mol Biol Rev 61: 533-534 (1997).

- 44Sakurai $N$ and Sakurai T, Isolation and characteristerization of nitric oxide reductase from Paracoccus halodenitrificans. Biochemistry 36: 13 809-13 815 (1997).

- 45Lee KH and Sublette KL, Reduction of nitric oxide to elemental nitrogen by Thiobacillus denitrificans. Appl Biochem Biotechnol 24-25: 441-445 (1990).

- 46Lee KH and Sublette KL, Simultaneous combined microbial removal of sulfur dioxide and nitric oxide from a gas stream. Appl Biochem Biotechnol 28-29: 623-634 (1991).

- 47Dasu BN, Deshmane V, Shanmugasundram R, Lee CM and Sublette KL, Microbial reduction of sulfur dioxide and nitric oxide. Fuel 72: 1705-1714 (1993).

- 48Potter WT, Cho J and Sublette KL, Reduction of nitric oxide to nitrous oxide by cobalt porphyrins and corrins. Fuel Process Technol 40: 355-360 (1994).

- 49Potter WT, Le U, Ronda S, Cho JG, Shanmugasundram R, Chirkis A and Sublette KL, Biomimetic and microbial reduction of nitric oxide. Appl Biochem Biotechnol 5152: 771-784 (1995).

- 50Arvidsson P, Nilsson K, Hakanson H and Mattiasson B, Monitoring nitric oxide from immobilised denitrifying bacteria, Pseudomonas stutzeri, by the use of chemiluminescence. Appl Microbiol Biotechnol 49: 677-681 (1998).

- 51Samdani G, Microbes nosh on NOx in flue gas. Chem Eng 100: 25-27 (1993).

- 52Apel WA and Turick CE, The use of denitrifying bacteria for the removal of nitrogen-oxides from combustion gases. Fuel 72: 1715-1718 (1993).

- 53Barnes JM, Apel WA and Barrett KB, Removal of nitrogen oxides from gas streams using biofiltration. J Hazard Mater 41: 315-326 (1995).

- 54Apel WA, Barnes JM and Barrett K, Biofiltration of nitric oxide from fuel combustion gas streams. Proceedings, $88^{\text {th }}$ Annual Meeting, Air and Waste Management Association, San Antonio, TX, June 18-23 (1995).

- 55Lee BD, Apel WA and Smith WA, Effect of oxygen on thermophilic denitrifying populations in biofilters treating nitric oxide containing off-gas streams. Proceedings, 
$92^{\text {nd }}$ Annual Meeting, Air and Waste Management Association, St Louis, Missouri, June 20-24 (1999).

- 56Lee BD, Apel WA and Smith WA, Oxygen effects on thermophilic microbial populations in biofilters treating nitric oxide containing off-gas streams. Environ Prog 20: 157-166 (2001).

- 57Klasson KT and Davison BH, Effect of temperature on biofiltration of nitric oxide. Appl Biochem Biotechnol 91-93: 205-211 (2001).

- 58Lacey JA, Lee BD and Apel WA, PCR-DGGE as a method to monitor microbial populations in nitric oxide biofilters. Proceedings, 95 ${ }^{\text {th }}$ Annual Meeting, Air and Waste Management Association, Baltimore, MD, June 23-27 (2002).

- 59du Plessis CA, Kinney KA, Schroeder ED, Chang DPY and Scow KM, Denitrification and nitric oxide reduction in an aerobic, toluene-treating biofilter. Biotechnol Bioeng 58: 408-415 (1998).

- 60Kennes $C$ and Veiga MC, Inert filter media for the biofiltration of waste gasescharacteristics and biomass control. Re/Views in Environmental Science and Bio/Technology 1: 201-214 (2002).

- 61Flanagan WP, Apel WA, Barnes JM and Lee BD, Development of gas phase bioreactors for the removal of nitrogen oxides from synthetic flue gas streams. Fuel 81: 1953-1961 (2002).

Cr• 62Chagnot E, Taha S, Martin G and Vicard JF, Treatment of nitrogen oxides on a percolating biofilter after pre-concentration on activated carbon. Process Biochem 33: 617-624 (1998).

- 63Lebedeva EV, Stepanov AL, L'Vov NP, Hinz M and Bok E, Consumption of nitrogen oxide by a strain of Bacillus stearothermophilus and its use in a bioreactor for air purification. Appl Biochem Microbiol 34: 559-563 (1998).

- 64Kennes $C$ and Veiga MC, Fungal biocatalysts in the biofiltration of VOC-polluted air. J Biotechnol 113: 305-319 (2004).

- 65Shoun H and Tanimoto T, Denitrification by the fungus Fusarium-oxysporum and involvement of cytochrome-P-450 in the respiratory nitrite reduction. J Biol Chem 266: 11 078-11 082 (1991).

- 66Shoun H, Kim DH, Uchiyama H and Sugiyama J, Denitrification by fungi. FEMS Microbiol Lett 94: 277-281 (1992).

- 67Takaya $N$ and Shoun $H$, Nitric oxide reduction, the last step in denitrification by Fusarium oxysporum, is obligatorily mediated by cytochrome P450nor. Mol Gen Genet 263: 342-348 (2000).

- 68Hendriks J, Oubrie A, Castresana J, Urbani A, Gemeinhardt S and Saraste M, Nitric oxide reductases in bacteria. Biochim Biophys Acta-Bioenerg 1459: 266-273 (2000).

- 69Yoshihara KI, Nagase H, Eguchi K, Hirata K and Miyamoto K, Biological elimination of nitric oxide and carbon dioxide from flue gas by marine microalga NOA113 cultivated in a long tubular photobioreactor. J Ferment Bioeng 82: 351-354 (1996).

- 70Nagase H, Yoshihara K, Eguchi K, Yokota Y, Matsui R, Hirata K and Miyamoto K, Characteristics of biological NOx removal from flue gas in a Dunaliella tertiolecta culture system. J Ferment Bioeng 83: 461-465 (1997). 
- 71Nagase H, Eguchi K, Yoshihara K, Hirata K and Miyamoto K, Improvement of microalgal NOx removal in bubble column and airlift reactors. J Ferment Bioeng 86: 421-423 (1998).

- 72Nagase H, Yoshihara K, Eguchi K, Okamoto Y, Murasaki S, Yamashita R, Hirata $K$ and Miyamoto K, Uptake pathway and continuous removal of nitric oxide from flue gas using microalgae. Biochem Eng J 7: 241-246 (2001).

- 73Shi Y, Littlejohn D and Chang SG, Integrated tests for removal of nitric oxide with iron thiochelate in wet flue gas desulfurization systems. Environ Sci Technol 30: 33713376 (1996).

- 74Shi Y, Wang H and Chang SG, Kinetics of NO absorption in aqueous iron(II) thiochelate solutions. Environ Prog 16: 201-206 (1997).

- 75Cetinkaya B, Sahlin RK, Abma WR, Dijkman H, Meyer SF and Kampeter SM, Control FCC flue gas emission. Hydrocarb Process 79: 55-62 (2000).

- 76Kumaraswamy R, Muyzer G, Kuenen JG and van Loosdrecht MCM, Biological removal of NOx from flue gas. Water Sci Technol 50: 9-15 (2004).

- 77van Groenestijn JW, Bioscrubbers, in Bioreactors for Waste Gas Treatment, ed by KennesC and VeigaMC. Kluwer Academic Publishers, Dordrecht, The Netherlands, pp 133-162 (2001).

- 78van der Maas P, Klapwijk B and Lens P, BioDeNOx: novel process for NOx removal from flue gases based on chemically enhanced biological NO and iron reduction, in Proceedings of the European Symposium on Environmental Biotechnology, Ostend, Belgium, ed by VerstraeteW pp 341-344 (2004).

- 79Gambardella F, Fabianti S, Galan LM, Ganzeveld KJ and Heeres HJ, NO removal from flue gases: the kinetics of the oxidation of $\mathrm{Fe}^{2+}$ (EDTA) under typical BioDeNOx conditions, in Proceedings of the European Symposium on Environmental Biotechnology, Ostend, Belgium, ed by VerstraeteW pp 873-877 (2004).

- 80van der Maas P, Harmsen L, Weelink S, Klapwijk B and Lens P, Denitrification in aqueous FeEDTA solutions. J Chem Technol Biotechnol 79: 835-841 (2004). 